\title{
CONDITIONS FOR DEVELOPMENT OF COMPANIES' COOPERATION AND ENTREPRENEURSHIP
}

\author{
Andrzej Daniluk ${ }^{1}$, Anna Tomaszuk ${ }^{2}$ \\ ${ }^{2}$ Faculty of Management, Bialystok University of Technology, \\ 2 O. St. Tarasiuka Street, 16-001 Kleosin, Bialystok, Poland \\ E-mails: '1a.daniluk@pb.edu.pl; ${ }^{2}$ a.tomaszuk@pb.edu.pl (corresponding author)
}

\begin{abstract}
The aim is to point out the factors of cooperation between firms working in the same branch of industry. The article uses the method of critical analysis of literature and statistical analysis of data obtained from a survey conducted in Polish metal and machine companies, which are one of leading industries in Podlaskie voivodeship. Analyzed were primarily: the evaluation of the level of existing cooperation; the impact of each factor on the current level of cooperation and the impact of positive changes on improving the current level of cooperation. To improve cooperation between competing companies more proactive approach of the research centers and business incubators is recommended in linking the potential areas of cooperation.
\end{abstract}

Keywords: cooperation, entrepreneurship, enterprises development, metal industry.

JEL Classification: L22; L26.

\section{Introduction}

Changes in behavior of entities reflected in the increasing number and types of forms of cooperation between companies have been observed for 30 years (Powell 1990; Noteboom 1999; Powell et al. 1996; Świadek, Wiśniewska 2015). Strategies of enterprises have also changed and the key success factors are now not only to minimize costs - economic effects resulting from combining resources of companies are becoming increasingly important (Strzyżewska 2011).

Different forms of cooperation between companies make now one of the ways of business operations - cooperation is a permanent mechanism for allocation of resources, and strategic partnership for a long time is a requirement for effective management (Sulejewicz 1997). For a long time cooperation between organizations has been regarded as a facilitator of innovations ( $\mathrm{Tu}$ et al. 2014; Florida 2007; Tu 2009).

Polish presence in the EU, more frequent appearance of global companies in our country and increasing international activities of Polish enterprises contribute to the fact that new possibilities are opening to them. The specificity of a large number of Polish enterprises - in particular insufficient additional investment and lack of capital, combined with progressive liberalization of the world of economy, make participation in the network of global corporation alliances an interesting alternative for companies (Sroka 2012; Nurullah et al. 2012); and cooperation at the sector level is often a necessity - the company's ability to build partnerships with business partners is one of the manifestations of the ability to achieve competitive advantage (Adamik, Staniszewska 2008).

The factor limiting the possibilities for industry development in Podlasie is the distance from the Western markets, which reduces the possibility of drawing experience and capital. Companies operating in close proximity to Western Europe have greater opportunities for cooperation and exchange of experience with the world's biggest corporations. The result is the sale of manufactured goods on both domestic and international markets. Despite this, we can state that Podlaskie is a region where enterprises development is possible through, for example, creation of cooperation structures operating in cross-border relations.

In the last two decades the specificity of cooperation development was creating cooperation between competitors (actual, but also potential) rather than vertical cooperation or integration, because these are the forms that have been developed for a long time (Cygler 2009).

The aim of this article was to present the results of studies which take into account factors affecting the level of cooperation of enterprises operating in the same sector, in the context of opportunities for development of entrepreneurship. The article uses the method of critical analysis of the literature and statistical analysis of data obtained 
from a study conducted on a group of companies representing the metal and machine industry in the north-eastern Poland.

\section{Literature review}

The complex environment of contemporary business reality requires enterprises to have the skills not only to compete, but also to cooperate (Wasiluk 2013). The prerequisite to work together is a common interest resulting in the need to strengthen the potential in different arenas (Hamel 1991; Håkansson 1987; Inkpen, Crossan 1996). Cooperation between companies is becoming increasingly important, and network organizations are an increasingly common form of functioning in the world of business (Sroka, Cygler 2014) - in the modern global economy a dynamic development of various forms of cooperation between economic operators is also observed (Wybieralski 2015), basic types of interaction are presented in Figure 1.

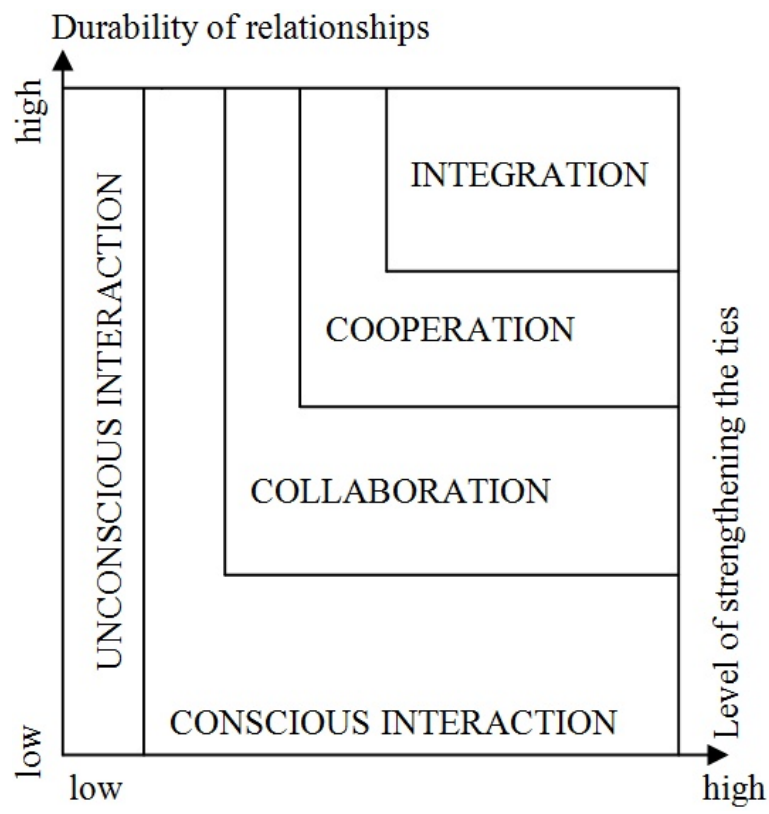

Fig. 1. Types of interaction (Source: Tomski 2008)

Modern economy is a network of related companies with different relations - voluntary or forced - that bring both benefits and losses. Each market operator is involved in a variety of relationships with other entities in the business environment (Strzyżewska 2011). Their basic types are presented in Table 1.

Analyzing the table information we can see that competition and cooperation are not opposing concepts, although a number of differences can be observed between them. The basic differences would include the way of thinking, emotions felt
Table 1. Types of relations in the sector (Source: Strzyżewska 2011)

\begin{tabular}{l|l|l|l}
\hline $\begin{array}{l}\text { Type of } \\
\text { relation }\end{array}$ & Emotions & \multicolumn{1}{|c}{ Action } & \multicolumn{1}{|c}{ Results } \\
\hline Conflict & Hostility & $\begin{array}{l}\text { Struggling to } \\
\text { eliminate the } \\
\text { rival from } \\
\text { the market }\end{array}$ & Monopoly \\
\hline $\begin{array}{l}\text { Compe- } \\
\text { tition }\end{array}$ & Rivalry & $\begin{array}{l}\text { Striving for } \\
\text { domination }\end{array}$ & $\begin{array}{l}\text { Competitive } \\
\text { advantage }\end{array}$ \\
\hline $\begin{array}{l}\text { Coex- } \\
\text { istence }\end{array}$ & $\begin{array}{l}\text { Lack of } \\
\text { commit- } \\
\text { ment }\end{array}$ & $\begin{array}{l}\text { Independent } \\
\text { actions }\end{array}$ & $\begin{array}{l}\text { Niche mar- } \\
\text { ket, avoiding } \\
\text { competition }\end{array}$ \\
\hline Help & Kindness & $\begin{array}{l}\text { Exceptional } \\
\text { actions }\end{array}$ & $\begin{array}{l}\text { Better rela- } \\
\text { tions in the } \\
\text { sector }\end{array}$ \\
\hline $\begin{array}{l}\text { Cooper- } \\
\text { ation }\end{array}$ & $\begin{array}{l}\text { Under- } \\
\text { standing } \\
\text { the inter- } \\
\text { depend- } \\
\text { ence }\end{array}$ & $\begin{array}{l}\text { Common } \\
\text { actions }\end{array}$ & $\begin{array}{l}\text { The survival } \\
\text { of the sector } \\
\text { and faster } \\
\text { development } \\
\text { of the coop- } \\
\text { erating } \\
\text { companies }\end{array}$ \\
\hline $\begin{array}{l}\text { Con- } \\
\text { spiracy }\end{array}$ & $\begin{array}{l}\text { Greed } \\
\text { and } \\
\text { deceit }\end{array}$ & $\begin{array}{l}\text { The agree- } \\
\text { ment of } \\
\text { several enti- } \\
\text { ties targeted } \\
\text { for removal } \\
\text { from the } \\
\text { market }\end{array}$ & $\begin{array}{l}\text { Oligopoly, } \\
\text { mafia } \\
\text { structures }\end{array}$ \\
\hline
\end{tabular}

and conduct of behavior. While the goal of competition is to win - the aim of cooperation is continuous development. In addition, participants of networking feel they are part of the sector and notice the raison d'être of other companies in the sector. While working with competitors we treat them as allies, not enemies, therefore there is no resentment or hatred for the competitor. Accordingly, the dominant behavior in cooperation is fair treatment of the competitor, while the characteristic feature of competing is separation from other companies (Strzyżewska 2011). Companies in the same sector may also act differently depending on the stage of their development - at the stage of identifying opportunities the entities often work together, at the stage of their use - they compete (Oliver 2004).

Nowadays in everyday language the concept of cooperation seems to be commonly understood and identified with undertaking joint actions in order to achieve mutual benefits. The elements repeated in definitions of cooperation presented in the literature are also cooperation and benefit.

In the literature, cooperation is defined as "relationship in which individuals, groups and organizations interact with each other by sharing or trans- 
fer of complementary skills and resources, and their development in order to achieve benefits for both sides" (Gnyawali, Madhaven 2006). Cooperation can also be understood as "taking measures to achieve a common goal, based on identification with this objective, trust, loyalty and acting in the interest of all participants while observing the accepted rules of communication and solving conflicts" (Czarniawski 2002). According to Strzyżewska (2011), collaboration is "a relationship that bounds at least two entities that involving cooperation, the aim of which is to achieve benefits by these entities, or - in case of cooperation forced to achieve benefits by some of these entities" (Strzyżewska 2011). Cooperation is an action that involves "coordination of partial tasks resulting from the division of work or from the links between economic entities on the basis of concluded contracts, agreements that prevent or facilitate the execution of specific tasks" (Połomska-Jasieniowska 2010). A key element of the cooperation is realization of a common goal. On this basis the ties are built between the various entities, based on mutual communication and leading to actions in common interest.

Factors supporting cooperation between organizations are mainly (Bembenek 2006):

- Mutual compatibility of purposes.

- Complementarity of actions.

- Awareness of the positive significance of common goals achievement by partners.

- Joint implementation of partial tasks.

- Voluntary cooperation (freedom to join and terminate).

- Formality or informality.

- Maintaining economic and legal independence by the participating partners.

These factors allow for consistent cooperation at the regional level and, thanks to improved conditions for business activities, they also create opportunities to generate competitive advantage on the level of economic groups and individual entities. This is due to the accumulation of resources of the cooperating organizations and their functional complementarity. The extent to which the needs of society are met will therefore depend on the level of cooperation between participants of the three sectors of the economy and the quality of relations between them (Bembenek 2006).

The process of cooperation between companies is affected by various reasons, among which the following factors should be in particular distinguished (Brojak-Trzaskowska 2004):

- Exchange of mutual benefits.

- Achieving a common goal.
- Implementation of innovative projects.

- Financing expensive founding investments, issuing of shares.

- Creation and operation of joint facilities.

- Participation in the financing and execution of complex technological processes.

- A desire to strengthen the position on existing markets or to master new markets.

- A possibility of risk sharing.

- Use of synergy effects.

- Protection of the interests of cooperating companies.

- Exchange of experiences.

- Trade in goods.

- Tightening up the competitive struggle.

- Increase of consumer requirements.

- Development of processes of production, exchange and consumption.

- Negligence of certain tasks and outsourcing them to other entities.

Undertaking extensive cooperation with operators in the industry enables (Pachciarek 2011):

- Rationalization of the use of organization's resources with a special focus on human resources in terms of access and training of professionals, acquisition and creation of new knowledge.

- Gaining a competitive advantage by enhancing innovation, better meeting the needs of customers.

- Achieving higher customer satisfaction.

- Reduction of operating costs due to diversification of risk sharing costs of innovative actions.

- Expansion of the market by raising the competitiveness of the global business groups.

In contrast, the most important factors hindering cooperation include primarily (Pachciarek 2011):

- Limited market resources leading to continuous rivalry.

- Lack of trust between entities.

- Legal restrictions related to anti-trust activities.

- A very strong culture of individualism in Poland, which makes it difficult and sometimes even impossible to target common goals because of the desire to meet individual interests of the individual players.

The horizontal cooperation may lead to "cannibalism" of the market. This means that within the built collaborative relationships the stronger party will seek to dominate the weaker players, which in turn leads to their elimination from the market or being absorbed by the stronger (Pachciarek 2011). 
In summary, the ability to create collaboration between businesses may lead to future joint problem solving, joint control over processes and mutual learning, but we should not forget that a large part of alliances fail to achieve both the goals and the assumed benefits by the cooperating companies (Kale, Singh 2009; Lunnan, Haugland 2008; Das, Teng 2000; Keasler, Denning 2009).

\section{Research methodology}

Taking the above into consideration the further part of this paper presents the results of partial research carried out in the framework of an international research project "Readiness of enterprises to create cross-border networking". The project resulted from an agreement between the Polish Academy of Sciences and the National Academy of Sciences of Belarus in 2014-2016. Quantitative studies, carried out in late 2014 and early 2015 on the basis of deliberate choice, covered 381 Polish enterprises of industries leading in Podlaskie province.

Podlaskie Province covers the north - east area of Poland and borders three countries: Lithuania, Belarus and Russia. The neighborhood affects the development of specific social ties and formation of cross-border economic links. Despite a considerable potential of the area and population, this region is characterized by a lower level of socio-economic development than other regions of Poland. This is particularly evident in the case of the province of Podlasie, whose social and economic potential is much smaller than the others, especially the central provinces.

Limitations of a market and low innovative potential of local companies make it crucial to accelerate the development of companies in Podlasie region through seeking broader cooperation. Extending the areas of cross-border cooperation may be a way to increase access to external markets, widening contacts of local communities, promotion of the region, attracting foreign investors and the use of international experience in the organization of regional cooperation. Previous experiences from cross-border cooperation of the metal industry companies in Podlaskie have been discussed in detail in the framework of earlier research (Wasiluk, Daniluk 2013).

This paper therefore is limited to the analysis of the results in terms of such issues as: the potential areas of cooperation between the surveyed companies within metal industry, declarations of the surveyed companies' willingness to undertake cooperation with partners in industry, the benefits resulting from cooperation for enterprises in metal industry, conditions of lack of cooperation or lack of interest in such cooperation in the cross-border area. The research approach based on Desk Research analysis was applied for realization of the set objectives. As a result of the literature analysis and ongoing discussions the factors shaping cooperation between enterprises have been determined in the context of strengthening the development of entrepreneurship. An analysis was carried out of factors affecting the level of cooperation on the basis of the available statistical data and source materials.

The structure of researched companies is presented in Figure 2.
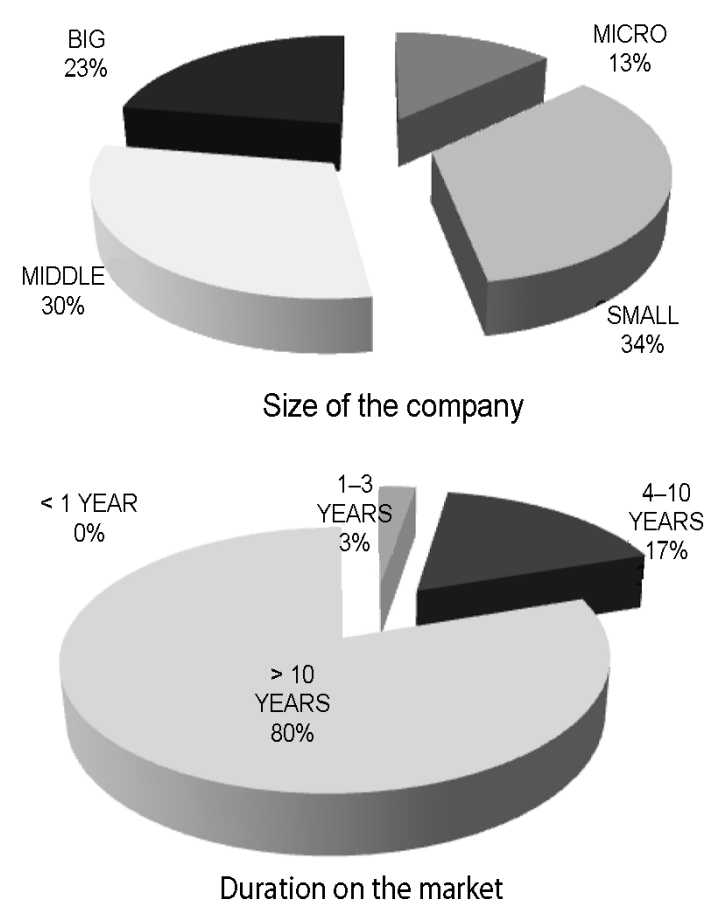

Fig. 2. Overall structure of the analyzed companies (Source: own study based on the research results)

The biggest group of respondents, according to their size, was small companies (34\%). $30 \%$ of the researched companies were middle companies and $23 \%$ - big firms. Over $80 \%$ of the researched units have existed on the market for more than 10 years. They are therefore well established companies although the majority of them are still in the group of small and middle.

The adopted methodical concept of the research involved:

- Developing the guidelines for analyzing the current situation in the field of cooperation between enterprises in the examined sector and the conditions for joint 
actions of entrepreneurs in the metal industry, in the context of enterprise development in the border regions.

- Indicating directions of change in needs for support of cooperative activities within the metal industry.

- Developing the guidelines and recommendations related to building effective cooperation links.

Taking the literature into consideration it was assumed that undertaking certain forms of mutual cooperation with companies in the sector can increase the propensity for the development of innovative activities. It may therefore be beneficial to the development of entrepreneurship in the individual entities within the framework of cooperative relations. Competing companies that operate within the industry are not strangers to each other and the cooperation in different types of structures, especially in a cluster network, can increase the effect of mutual support by providing options in the form of the potential of others. The research questions included the importance of different conditions for the willingness to undertake mutual cooperation between companies operating within the industry. Defining the key factors led to identification of potential cooperation spheres and the importance of these factors for the development of entrepreneurship (Fig. 3).

\section{Analysis of the results and discussion about them}

Detailed analyzes regarding the potential cooperation between enterprises in the metal industry, in the context of conditions for entrepreneurship development, aimed at getting answers to the following research questions:

1) How do the respondents evaluate the current level of cooperation between companies in the metal and machine industry?

2) How do the respondents evaluate the degree of interest in tigthening the cooperation between companies in the metal and machine industry in the near future?

3) To what extent do the various factors influence the current level of cooperation between companies in the metal and machine industry?

4) To what extent the positive changes in various factors may contribute to the improvement of the current level of cooperation between the companies in the metal and machine industry in the near future?

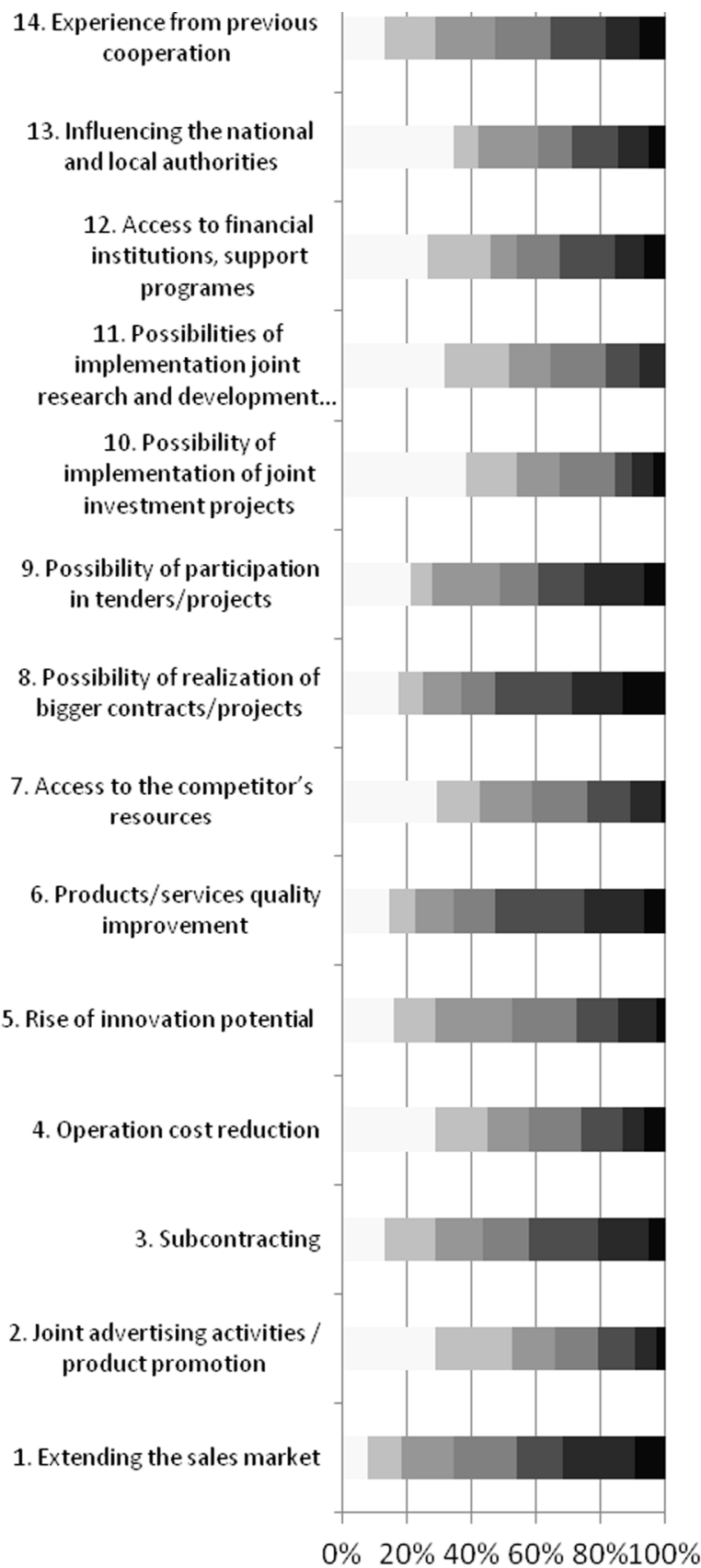

$1 \square 2 \square 3 \square 4 \square 5 \square 6 \square 7$

Fig. 3. The structure of answers on current level of cooperation in the metal and machine industry

(Source: own study based on the research results)

The research results show a great variety in perception of factors affecting the possibility of cooperation in particular groups of enterprises (Fig. 3). On the basis of the previous research (Wasiluk, Daniluk 2013) we can define the lack of trust between companies in the business to be an important factor limiting the spread of information about benefits of cooperation. Different companies were not interested in transferring of information to the other companies regarding it would potentially weaken their market position. 
The results of the research were coded, and the primary data obtained was subject to organizing, grouping and analysis using statistical tools such as: tabular forms of data presentation; descriptive statistics; nonparametric statistics. The analysis were conducted with the use of the statistical package StatSoft STATISTICA ${ }^{\circledR}$ Version 12.5. In terms of the evaluation of conditions for entrepreneurship development in the metal and machine industry companies operating in Podlaskie province, an important element of the study was the question of the assessment of the current level of cooperation and the degree of interest in its tightening in the future. The researched companies were asked for self-evaluation through the prism of the indicated factors. The respondents evaluated the above factors in the seven-point scale (Table 2).

Table 2. Evaluation of the level of current cooperation in the metal and machine industry and the degree of interest in its tightening in the future (Source: own study based on the research results)

\begin{tabular}{|c|c|c|c|}
\hline & $\bar{x}$ & $D$ & $V$ \\
\hline Level of cooperation & 3,84 & 4 & 41,44 \\
\hline $\begin{array}{l}\text { Degree of interest in } \\
\text { strengthening cooperation } \\
\text { within the next } 2-3 \text { years }\end{array}$ & 3,99 & 4 & 40,65 \\
\hline \multicolumn{4}{|l|}{ Spearman's rank correlations } \\
\hline \multicolumn{3}{|c|}{$\begin{array}{l}\text { Evaluation of the current level of coopera- } \\
\text { tion and possibilities of its strengthening in } \\
\text { the future }\end{array}$} & 0,36 \\
\hline
\end{tabular}

The obtained results indicate that respondents evaluated the current level of cooperation with entities in the industry at the average rate (average score -3.84 ). They were also quite unanimous in their evaluations, as evidenced by the value of a statistical indicator for response variations $(\mathrm{V}=$ 41.44). The largest group of those who responded evaluated the current level of cooperation at 4 in the seven-point scale (Dominant $\mathrm{D}=4$ for groups of 20 subjects participating in the survey). We can therefore speak of a relatively optimistic approach to this issue. Equally optimistically we should look at the results of the evaluation of interest in tightening cooperation with companies in the industry. The average note was 3.99 with the median at the current level equal to 4 . Among the surveyed entities cooperating in the industry the interest is evident in tightening mutual cooperation in the future in relation to the present. The dominant group of respondents indicates the need at level 3 .

Taking into account the received responses the statistical evaluation was made of the current level of cooperation impact on the possibility of its tightening in the future. The value of the Spearman's rank correlation indicates a significant level of interdependence between the studied features. Therefore, it can be concluded that the increase in evaluations of the current level of cooperation is accompanied by a significant increase in the degree of interest in tightening this cooperation in the next 2-3 years. The increase of interest in tightening cooperation may be affected by its results so far - felt directly and indirectly by cooperating entities. This depends largely on mutual expectations and the expected and actually received benefits from the cooperation.

Table 3. Factors affecting the current level of cooperation in the metal and machine industry (Source: own study based on the research results)

\begin{tabular}{|c|c|c|c|}
\hline Factor & $\bar{x}$ & $D$ & $V$ \\
\hline 1. Extending the sales market & 4,26 & 6 & 41,50 \\
\hline $\begin{array}{l}\text { 2. Joint advertising activities / } \\
\text { product promotion }\end{array}$ & 2,86 & 1 & 60,99 \\
\hline 3. Subcontracting & 3,83 & 5 & 47,37 \\
\hline 4. Operation cost reduction & 3,14 & 1 & 60,94 \\
\hline 5. Rise of innovation potential & 3,47 & 3 & 48,05 \\
\hline $\begin{array}{l}\text { 6. Products/services quality im- } \\
\text { provement }\end{array}$ & 4,13 & 5 & 44,43 \\
\hline $\begin{array}{l}\text { 7. Access to the competitor's } \\
\text { resources }\end{array}$ & 3,04 & 3 & 57,73 \\
\hline $\begin{array}{l}\text { 8. Possibility of realization of } \\
\text { bigger contracts/projects }\end{array}$ & 4,16 & 5 & 48,43 \\
\hline $\begin{array}{l}\text { 9. Possibility of participation in } \\
\text { tenders/projects }\end{array}$ & 3,74 & 1 & 52,32 \\
\hline $\begin{array}{l}\text { 10. Possibility of implementation } \\
\text { of joint investment projects }\end{array}$ & 2,71 & 1 & 66,49 \\
\hline $\begin{array}{l}\text { 11. Possibilities of implementa- } \\
\text { tion joint research and devel- } \\
\text { opment activities }\end{array}$ & 2,79 & 1 & 59,50 \\
\hline $\begin{array}{l}\text { 12. Access to financial institu- } \\
\text { tions, support programes }\end{array}$ & 3,29 & 1 & 60,15 \\
\hline $\begin{array}{l}\text { 13. Influencing the national and } \\
\text { local authorities }\end{array}$ & 3,12 & 1 & 62,83 \\
\hline $\begin{array}{l}\text { 14. Experience from previous } \\
\text { cooperation }\end{array}$ & 3,72 & 3 & 48,56 \\
\hline
\end{tabular}

Identified were the interacting factors that constitute the mechanism of mutual cooperation between companies in the sector. Examined was also the extent to which various factors affect the evaluation of the current level of cooperation between the respondents' companies and cooperators in the industry. The results are shown in Table 3.

Analyzing the average values we can notice that the indications of above 4 apply to aspects of 
cooperation related to the expansion of the market, improving the quality of products and services and enabling realization of large orders. These are the areas that do not require mutual commitment to business cooperation on the basis of trust. They neither need to share their resources, which are associated with the development of entrepreneurship and innovativeness. Low ratings in areas that have a particularly significant impact on the development of entrepreneurship in the framework of joint actions can raise anxiety about the mechanisms of cooperation with entities in the industry.

The following can be mentioned here: implementation of joint investment projects (average rating 2.71), undertaking joint research and development activities with competitors (average 2.79). Slightly higher rated were factors associated with advertising activities (average rating 2.86), access to the resources of a competitor (3.04) or the increase of innovation potential (3.47). These are aspects that require a higher level of mutual commitment to cooperation and therefore - condition its greater durability.

The indicated evaluations might suggest lack of willingness on the part of companies cooperating in the industry to engage in deeper cooperation relationship, characterized by engaging their own resources and greater difficulty breaking it. It requires mutual trust and taking into account the interests of the cooperating parties. This was also confirmed by the results of other studies in which the primary factor limiting willingness to cooperate was a very low level of trust or even lack thereof that limited the potential to establish contacts between companies operating in the industry (Wasiluk, Daniluk 2013; Wasiluk, Daniluk 2014).

Respondents were also asked to evaluate the impact of positive changes in the various factors on improvement of the level of cooperation with the cooperators in the sector in the next 2-3 years. For the vast majority of the factors of the value of the average rating was higher than the current status of cooperation and reached satisfactory values. The highest increase in the evaluations of the impact of changes in the factors on improvement of cooperation in the industry in the future concerned the reduction of operating costs and increase of innovation potential.

This indicates mainly the market motivations - the potential possibility for using the results of cooperation to strengthen the competitive position in the industry (Fig. 4).

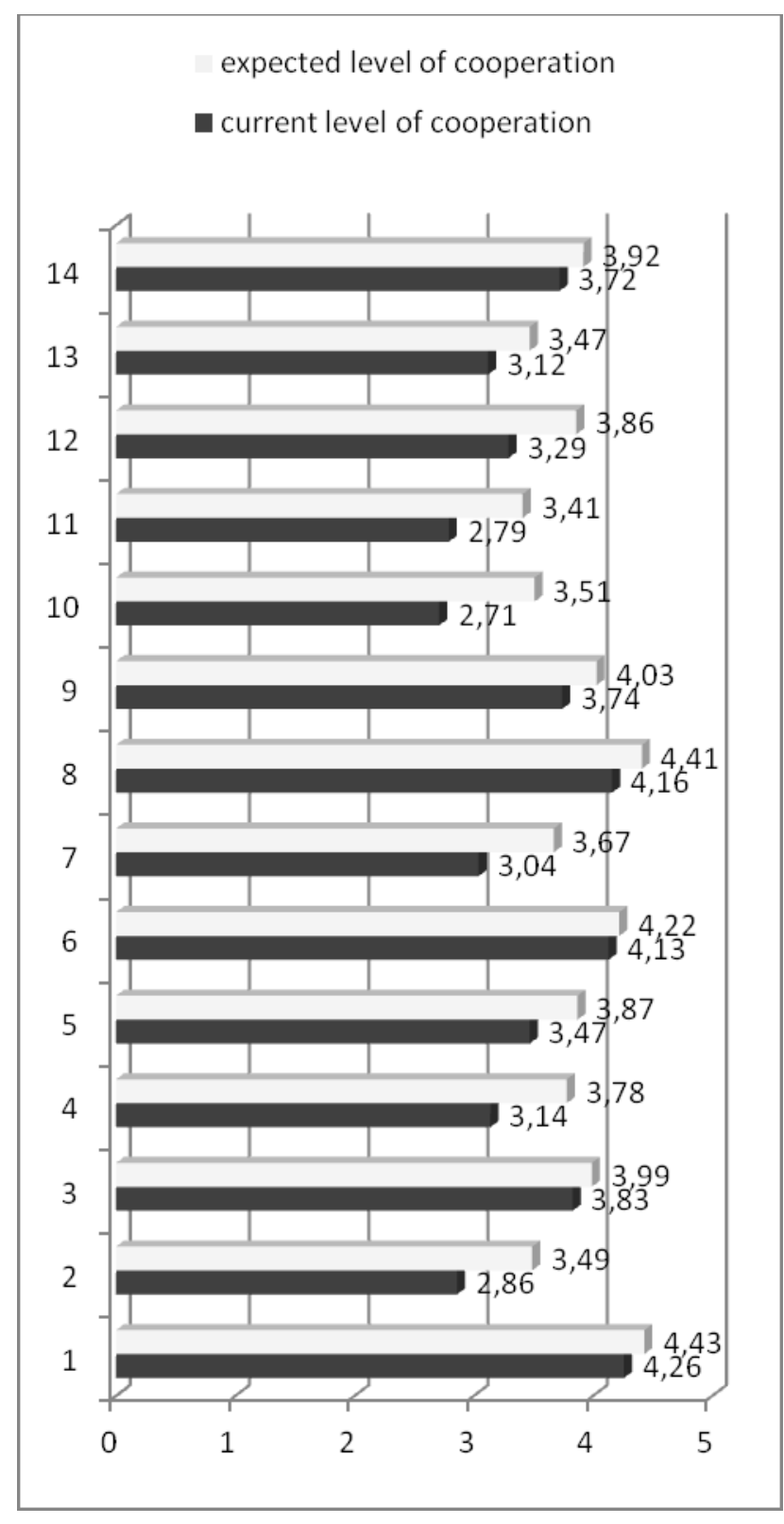

Fig. 4. The average values of evaluations of the current level of cooperation and the impact of positive changes in the various factors on the future level of cooperation - factor's numbers as in Table 3

(Source: own study based on the research results)

\section{Conclusions}

The text highlights the conditions regarding willingness to cooperate among companies operating in the metal industry in Podlaskie province in terms of business development. The existing interactions between the actors play an important role in this case. They include aspects such as economic cooperation and cooperention that constitute an important manifestation of the entrepreneurial skills. This is particularly important in case of the smaller enterprises, which often reach a certain stage of development and need new technologies 
to grow further. With too little potential, they are not able to conduct research and development activities independently and at the same time modernize technology and technological equipment that may already be outdated. At this point, there is a chance for the joint use of the competing companies' resources.

The research was conducted among a group of enterprises in the metal and machine industry, which is one of the leading industries in the region of north-eastern Poland regarding the level of entrepreneurship. The results show that in the researched group of companies a moderate degree of interest in undertaking cooperation with other entities in the industry can be observed. A higher rating of current level of contacts with companies in the industry translates into a greater willingness to cooperate in the future. From the point of view of entrepreneurship development, as an important carrier of innovation, it is apparent that the mechanisms of competition and achieving a better position in the studied industry outweigh the need for cooperation between the parties. The owners of the surveyed entities lack a positive reflection on the potential benefits of entering into various forms of cooperation.

Metal industry in the area of manufacturing machinery, equipment, components and metal parts and welded structures and products bases on recently growing in Podlasie specialization in the field of machinery parts construction, agricultural machinery, specialized equipment and steel structures. After the changes in the nineties a number of companies with national capital began to operate in the Podlasie region and in recent years they have begun to gain the experience on the international market. An important limitation to their further development is the location of metal companies, with foreign capital and links with the modern metal industry in Europe, in the western provinces of Poland. On the other hand, it contributes to stimulation of entrepreneurship and searching by local entities innovative solutions to be able to compete with strong in capital Western corporations. This is a field to establish wider cooperation in the industry and strengthen contacts also in terms of cross-border cooperation - for example, with entities from Lithuania.

The dynamic development of the industry is possible because of getting a recognized European position by leading producers of final products who offer highly advanced, innovative products, developed on the basis of the regional R\&D potential. Simultaneously, there is a possibility of expanding the network of companies, suppliers and independent producers on the basis of close network cooperation with leading manufacturers of final products and by using the regional research and development and educational potentials.

\section{References}

Adamik, A.; Staniszewska, K. 2008. Zarządzanie współpracą z partnerami biznesowymi z wykorzystaniem rozwiązań IT, in S. Lachiewicz, A. Zakrzewska-Bielawska (Eds.). Zarzadzanie przedsiębiorstwem $w$ warunkach rozwoju wysokich technologii. Łódź: Politechnika Łódzka.

Bembenek, B. 2006. Wokół koncepcji współdziałania, Studia Europejskie 5: 34-36.

Brojak-Trzaskowska, M. 2004. Zarządzanie jakością a innowacyjność przedsiębiorstw w warunkach kooperacji - wzajemne relacje, in W. Downar (Ed.). Rola kooperacji $w$ rozwoju społeczno-gospodarczym. Szczecin: PTE.

Cygler, J. 2009. Kooperencja przedsiębiorstw. Czynniki sektorowe i korporacyjne. Warszawa: SGH.

Czarniawski, H. 2002. Współdziałanie potrzeba czasu. Lublin: Norbertinum.

Das, T. K.; Teng, B. 2000. Instabilities of strategic alliances: an internal tensions perspective, Organization Science 11: 77-101. http://dx.doi.org/10.1287/orsc.11.1.77.12570

Florida, R. 2007. The flight of the creative class. The new global competition for talent. New York: Harper Collins.

Gnyawali, D. R.; Madhaven, J. H. R. 2006. Impact of co-opetition on firm competitive behaviour. An empirical examination, Journal of Management 32 (4): 507-509. http://dx.doi.org/10.1177/0149206305284550

Håkansson, H. 1987. Industrial technological development. A network approach. London: Croon Helm.

Hamel, G. 1991. Competition for competence and interpartner learning within international strategic alliances, Strategic Management Journal 12: 83-104. http://dx.doi.org/10.1002/smj.4250120908

Inkpen, A. C.; Crossan, M. 1996. Believing is seeing: joint ventures and organizational learning, Journal of Management Studies 32(5): 596-618.

Kale, P.; Singh, H. 2009. Managing strategic alliances: what do we know, and where do we go from here? Academy of Management Perspectives 23: 45-62. http://dx.doi.org/10.5465/AMP.2009.43479263

Keasler, T. R.; Denning, K. C. 2009. A re-examination of corporate strategic alliance. New Market Responses, Quarterly Journal of Finance and Accounting 48: 21-40.

Lunnan, R.; Haugland, S. A. 2008. Predicting and measuring alliance performance: a multidimensional analysis, Strategic Management Journal 29: 545-556. http://dx.doi.org/10.1002/smj.660 
Noteboom, B. 1999. The dynamic efficiency of networks, in A. Grandori (Ed.). Interfirm networks: Organization and industrial competitiveness. London: Routhledge. http://dx.doi.org/10.4324/9780203022481.pt2

Nurullah, G.; Nihat, A.; Öykü, N. Ï. 2012. A conceptual model proposal for determinants, form, functions and structure choice in strategic alliances, Procedia Social and Behavioral Science 58: 1594-1600. http://dx.doi.org/10.1016/j.sbspro.2012.09.1146

Oliver, A. L. 2004. On the duality of competition and collaboration: network - based knowledge relations in the biotechnology industry, Scandinavian Journal of Management 20(1): 151-171. http://dx.doi.org/10.1016/j.scaman.2004.06.002

Pachciarek, H. 2011. Czynniki sprzyjające i utrudniające współpracę pomiędzy organizacjami, Master of Business Administration 1(116): 30-42.

Połomska-Jasieniowska, A. 2010. Wewnętrzne uwarunkowania współdziałania gospodarczego małych przedsiębiorstw, in M. Matejun (Ed.). Wyzwania $i$ perspektywy zarzqdzania $w$ matych $i$ średnich przedsiębiorstwach. Warszawa: C.H. Beck.

Powell, W. W. 1990. Neither market nor hierarchy: network form of organization, Research in Organizational Behaviour 12: 295-336.

Powell, W. W.; Koput, K. W.; Smith-Doerr, L. 1996. Interorganizational collaboration and the locis of innovation: networks of learning in biotechnology, Administrative Science Quarterly 41: 116-145. http://dx.doi.org/10.2307/2393988

Sroka, W. 2012. Sieci aliansów. Poszukiwanie przewagi konkurencyjnej poprzez wspótpracę. Warszawa: PWE.

Sroka, W.; Cygler, J. 2014. Pathologies in interorganizational networks, Procedia Economic and Finance 12: 626-635.

http://dx.doi.org/10.1016/S2212-5671(14)00387-6
Strzyżewska, M. 2011. Wspótpraca między przedsiębiorstwami - odniesienie do polskiej praktyki. Warszawa: Oficyna Wydawnicza SGH.

Sulejewicz, A. 1997. Partnerstwo strategiczne: modelowanie wspótpracy przedsiębiorstw. Warszawa: SGH.

Świadek, A.; Wiśniewska, J. 2015. Wspótpraca przedsiębiorstw a innowacje $i$ transfer technologii: wybrane aspekty. Szczecin: Naukowe Wydawnictwo IVG.

Tomski, P. 2008. Stratyfikacja współdziałania gospodarczego przedsiębiorstw w ujęciu praktycznym, in D. Kopycinska (Ed.). Konkurencyjność podmiotów rynkowych. Szczecin: Uniwersytet Szczeciński.

Tu, C. 2009. A multilevel investigation of factors influencing creativity in NPD teams, Industrial Marketing Management 37(1): 119-126. http://dx.doi.org/10.1016/j.indmarman.2007.10.001

Tu, C.; Hwang, S. H.; Wong, J. Y. 2014. How does cooperation affect innovation in micro-enterprises?, Management Decision 52(8): 1390-1409. http://dx.doi.org/10.1108/MD-07-2013-0388

Wasiluk, A. 2013. Zaufanie i współpraca pomiędzy przedsiębiorstwami w perspektywie budowy i rozwoju struktur klastrowych, Economics and Management 4: 49-66.

Wasiluk, A.; Daniluk, A. 2014. The attitude of Polish and Lithuanian companies towards cooperating in business clusters (results of research), CROMA Journal 2: 40-54.

Wasiluk, A.; Daniluk, A. 2013. The possibilities of creating cross - border clusters. Vilnius: Vilnius University Publishing House.

Wybieralski, P. 2015. Alianse technologiczne a strategiczne zachowania korporacji międzynarodowych na rynkach niedoskonatych. Toruń: Adam Marszałek. 